\title{
PERBANDINGAN TINGKAT PENGENALAN CITRA DIABETIC RETINOPATHY PADA KOMBINASI PRINCIPLE COMPONENT DARI 4 CIRI BERBASIS METODE SVM (SUPPORT VECTOR MACHINE)
}

\author{
Sari AyuWulandari ${ }^{1}$, Rudy Tjahyono ${ }^{2}$, Dian Retno Sawitri ${ }^{1}$
}

\begin{abstract}
Pattern recoqnition methods for image of diabetic retinopaty are influenced by differences in pigmentation. To help diabetic retinopathy image recognition is required a software. This paper presents the results of research on pattern recognition image of diabetic retinopathy, This study used the image of the yellow canal with Gabor filter.Characteristics that are taken from each image is characteristic of the mean, variance, skewness and entropy, followed by feature extraction with PCA (Principle Component Analysis).At PCA feature extraction, square matrix whose number of columns equal to the number of features is generated.There are four features used. These features are 4 PCs (Principle Component), ie, PC1, PC2, PC3 and PC4.From the combination of these features, we obtained six pairs that consist of two traits. By using a linear model of SVM will been selected the pair with the highest accuracy value. Based on the analysis, we obtained a couple PC1 and PC2 models that have the highest levels of learning $(100 \%)$ and the fastest recognition time, which is explicitly indicated by the smallest amount of support vector.
\end{abstract}

Intisari - Metode pengenalan pola citra retinopati diabetik beserta setting poinnya dipengaruhi oleh perbedaan pigmentasi. Untuk membantu pengenalan citra retinopati diabetic dibutuhkan sebuah perangkat lunak. Makalah ini menyajikan hasil penelitian tentang pengenalan pola citra retinopati diabetik. Dalam penelitian tersebut digunakan citra kanal kuning (yellow), dengan filter Gabor. Ciri yang diambil dari tiap citra adalah ciri rerata (means), ragam (varians), skewness dan entropy, yang dilanjutkan dengan ekstraksi ciri PCA (Principle Component Analysis). Pada ekstraksi ciri PCA, dihasilkan matriks bujur sangkar, yang jumlah kolomnya, sama dengan jumlah ciri. Ada 4 ciri yang digunakan, yang merupakan 4 buah PC (Principle Component), yaitu, PC1, PC2, PC3 dan PC4. Keempat ciri tersebut dikombinasikan sehingga diperoleh 6 pasangan yang beranggotakan 2 ciri. Dengan mengunakan model linear dari SVM akan dipilih pasangan dengan nilai akurasi tertinggi. Berdasarkan hasil analisis diperoleh model pasangan PC1 dan PC2 yang memiliki tingkat pembelajaran tertinggi $(100 \%)$ dan waktu pengenalan tercepat, yang secara eksplisit ditunjukkan dengan jumlah support vector terkecil.

Kata Kunci- Kanal Kuning, SVM, diabetic retinopathy, PCA

${ }^{1}$ Dosen Teknik Elektro Fakultas Teknik, Universitas Dian Nuswantoro, Jl. Nakula I No. 5-11 Semarang (tlp: 024-3555628; fax:024-355628; e-mail: sari.wulandari@dsn.dinus.ac.id; drsawitri@gmail.com)

${ }^{2}$ Dosen Teknik Industri Fakultas Teknik, Universitas Dian Nuswantoro, Jl. Nakula I No. 5-11 Semarang (tlp :024-3555628; fax:024-355628;rudytjahyono@yahoo.com)

Sari AyuWulandari: Perbandingan Tingkat Pengenalan Citra ...

\section{PENDAHULUAN}

Retinopati diabetik merupakan sebuah penyakit komplikasi yang berasal dari penyakit Diabetes Militus (untuk selanjutnya disingkat DM) [1]. Seseorang yang menderita DM akan terdapat kelainan pada retina-nya. Penderita lama-kelamaan akan mengalami kebutaan disebabkan oleh degradasi retina, baik kelainan pada pembuluh darahnya, pada optic disk, exudates, degradasi makula dan beberapa bagian retina yang lain.

Selama ini, pemeriksaan retinopati diabetik dilakukan dengan menggunakan bantuan citra retinopati, yang dihasilkan dari kamera fundus. Warna retina dipengaruhi oleh pigmentasi mata. Retina orang tropis akan berbeda dengan retina orang subtropis, yang dipengaruhi oleh intensitas mata terpapar matahari. Citra warna retina orang Indonesia cenderung gelap. Citra warnagelap yang dihasilkan oleh kamera fundus, menyebabkan sulitnya proses pendeteksian penyakit ini, ditambah dengan bagian retina yang halus dan kecil, menyebabkan terjadinya kesalahan dalam diagnosis. Selain itu, proses pendeteksian memakan waktu lama. Penelitian tentang system pengenalan pola citra retinopati diabetik telah dilakukan oleh beberapa peneliti dengan pendekatan yang berbeda-beda, yaitu dengan pengenalan optic disk [2-4], exudates [2,5,6,7], degradasi makula [8] dan pembuluh darah [9-11]. Metode yang dilakukan juga bervariasi, ada yang menggunakan pendekatan linear dengan menggunakan metode SVM (Support Vector Machine) [12] dan pendekatan titik pusat dengan FCM (Fuzzy C Means) [2,13,14] serta K-Means [15]. Penelitian tersebut menggunakan retina yang berasal dari database DRIVE (retina dari orang sub tropis), namun ciri retina orang Indonesia (tropis) berbeda dengan database DRIVE. Perbedaan citra retina diperlihatkan pada Gambar 1.

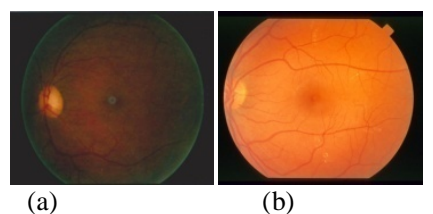

Gambar1. Database Citra (a) Orang Indonesia, (b) Drive (Digital Retinal Images for Vessel Extraction)

Perbedaan pigmentasi akan mempengaruhi metode pengenalan pola citra retinopati diabetik beserta setting poinnya. Untuk itu dibutuhkan sebuah perangkat lunak, yang mampu menjadi alat bantu pengenalan citra retinopati diabetik. Hal ini merupakan harapan baru bagi pengenalan citra retinopati diabetik. Penulis telah melakukan penelitian tentang pengenalan pola citra retinopati diabetik, dengan menggunakan citra kanal kuning (Yellow), dengan filter Gabor. Ciri yang p-ISSN:1693 - 2951; e-ISSN: 2503-2372

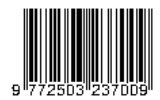


diambil dari tiap citra adalah ciri rerata (Means), ragam (Varians), skewness dan entropy, yang dilanjutkan dengan ekstraksi ciri PCA (Principle Component Analysis). Pada ekstraksi ciri PCA, Matriks hasil PCA merupakan matriks bujursangkar, yang jumlah kolomnya, sama dengan jumlah ciri. Penelitian dilakukan dengan menggunakan 4 ciri, sehingga, terdapat 4 buah PC (Principle Component) yang diberi nama PC1, PC2, PC3 dan PC4. Pada artikel ini akan dibahas mengenai tingkat akurasi tertinggi dari penggunaan pasangan PC. Tingkat akurasi, dihitung dengan menggunakan model linear dari SVM.

\section{METODE PENELITIAN}

Tingkat pengenalan citra retinopati diabetik, ditentukan melalui proses pembelajaran dan pengujian, ditunjukan pada Gambar 2.

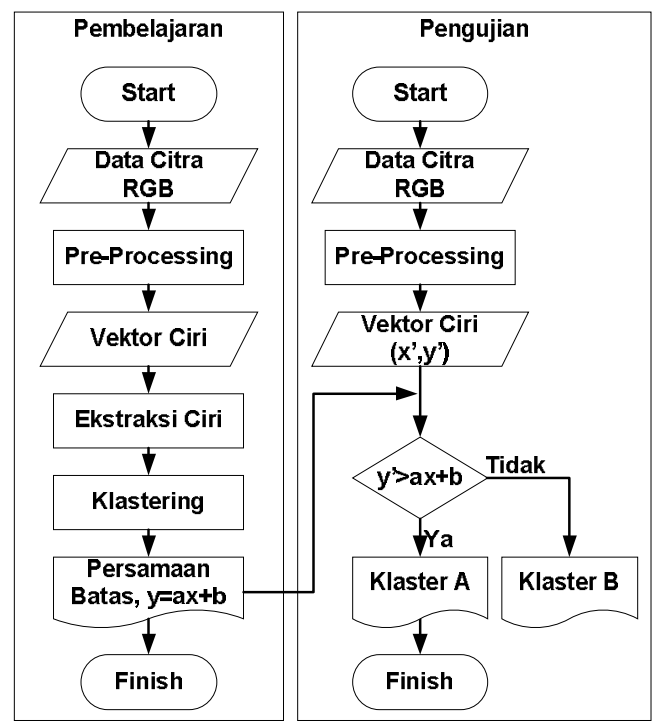

Gambar 2. Diagram Alir Pengenalan Citra

\section{A. Database Citra}

Database citra asli didapatkan dari database citra retina, Eye Centre Rumah Sakit Sultan Agung Semarang, yang berupa citra JPG dimensi $700 \times 605$ pixel, 8 bit. Citra tersebut, berasal dari kamera fundus Non-Mydriatic Retinal Camera $C R-D G i$. Contoh citra fundus diperlihatkan pada Gambar 3.Database citra retina dibagi menjadi 2 :

a. Data Pelatihan : terdiri dari 30 citra retina dan 30 citra non-retinopathy. Hasil pelatihan adalah sebuah model yang akan digunakan untuk menguji citra pengujian.

b. Data Pengujian : terdiri dari 30 citra retina dan 30 citra non-retinopati. Ke-60 citra pengujian merupakan citra diluar citra pelatihan atau bukan citra yang digunakan pada citra data pelatihan.

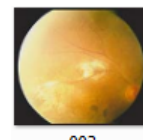

003

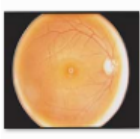

010

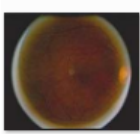

023

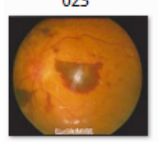

002

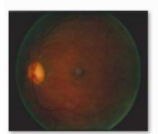

014

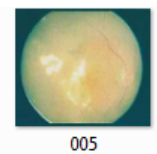

005

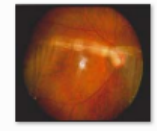

012

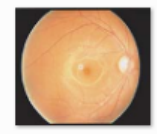

027

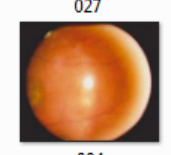

004

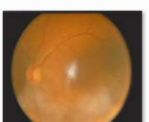

016

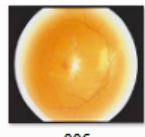

006

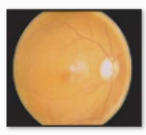

019

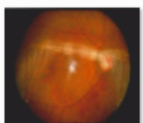

031
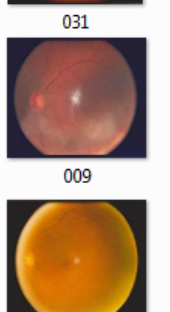

018

Citra Retina$$
\text { a }
$$

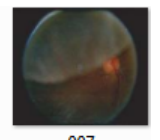

007

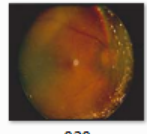

020

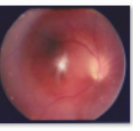

035

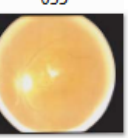

011

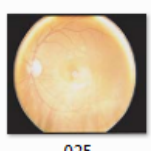

\section{B. Pre-Processing}

Tahap pre-processing merupakan tahap untuk melakukan penonjolan ciri dari citra retina. Penonjolan ciri dari penyakit diabetik dapat dilakukan dengan penonjolan bagian pembuluh darah, makula, eksudat ataupun optic disk. Pada artikel ini, dilakukan penonjolan pembuluh darah. Proses penonjolan ciri pembuluh darah diperlihatkan pada Gambar 4.

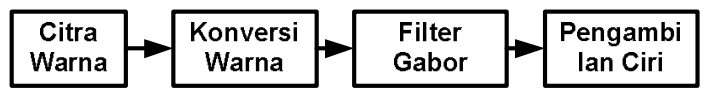

Gambar 4. Blok Diagram Pre-Processing

Proses pre-processing, merupakan proses awal untuk menyiapkan vektor ciri (feature vector). Untuk mendapatkan warna kuning (Y), citra warna RGB harus dikonversi menjadi citra YCbCr. Citra 3 kanal YCbCr, kemudian diambil 1 kanal saja yaitu pada kanal $\mathrm{Y}$.
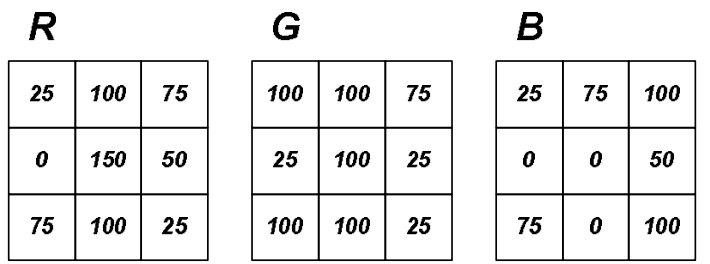

Gambar 5.Contoh Citra Warna RGB 3x3

Citra Y mempunyai kombinasi intesitas warna antara 0-255. Konversi citra RGB ke YCbCr menggunakan persamaan 1[16]. Contoh citra warna RGB 3x3, seperti yang terlihat pada Gambar 5.

$$
\begin{aligned}
& Y=0,299 R+0,587 G+0,114 B \\
& C b=-0,1687 R-0,3313 G+0,5 B+128 \\
& C r=0,5 R-0,4187 G-0,0813 B+128
\end{aligned}
$$


Jika terdapat citra warna RGB seperti pada Gambar 4, maka hasil perhitungan konversi warna dari RGB ke YCbCr adalah sebagai berikut :

\section{Kanal Y}

$Y(1,1)=(0,299 \times 25)+(0,587 \times 100)+(0,114 \times 25)=69,025$ $Y(1,2)=(0,299 \times 100)+(0,587 \times 100)+(0,114 \times 75)=97,15$ $Y(1,3)=(0,299 \times 75)+(0,587 \times 75)+(0,114 \times 100)=77,85$ $Y(2,1)=(0,299 \times 0)+(0,587 \times 25)+(0,114 \times 0)=14,675$ $Y(2,2)=(0,299 \times 150)+(0,587 \times 100)+(0,114 \times 0)=103,55$ $Y(2,3)=(0,299 \times 50)+(0,587 \times 25)+(0,114 \times 50)=35,325$ $Y(3,1)=(0,299 \times 75)+(0,587 \times 100)+(0,114 \times 75)=89,675$ $Y(3,2)=(0,299 \times 100)+(0,587 \times 100)+(0,114 \times 0)=88,6$ $Y(3,3)=(0,299 \times 25)+(0,587 \times 25)+(0,114 \times 100)=33,55$

\section{Kanal Cb}

$C b(1,1)=(-0,1687 \times 25)-(0,3313 \times 100)+(0,5 \times 25)+128=103,153$ $C b(1,2)=(-0,1687 \times 100)-(0,3313 \times 100)+(0,5 \times 75)+128=115,5$ $C b(1,3)=(-0,1687 \times 75)-(0,3313 \times 75)+(0,5 \times 100)+128=140,5$ $C b(2,1)=(-0,1687 \times 0)-(0,3313 \times 25)+(0,5 \times 0)+128=119,7175$ $C b(2,2)=(-0,1687 \times 150)-(0,3313 \times 100)+(0,5 \times 0)+128=69,565$ $C b(2,3)=(-0,1687 \times 50)-(0,3313 \times 25)+(0,5 \times 50)+128=136,2825$ $C b(3,1)=(-0,1687 \times 75)-(0,3313 \times 100)+(0,5 \times 75)+128=119,717$ $C b(3,2)=(-0,1687 \times 100)-(0,3313 \times 100)+(0,5 \times 0)+128=78$ $C b(3,3)=(-0,1687 \times 25)-(0,3313 \times 25)+(0,5 \times 100)+128=165,5$

\section{Kanal Cr}

$C r(1,1)=(0,5 \times 25)-(0,42 \times 100)-(0,0813 \times 25)+128=96,5975$

$C r(1,2)=(0,5 \times 25)-(0,42 \times 100)-(0,0813 \times 25)+128=130,0325$

$C r(1,3)=(0,5 \times 25)-(0,42 \times 100)-(0,0813 \times 25)+128=125,9675$

$C r(2,1)=(0,5 \times 25)-(0,42 \times 100)-(0,0813 \times 25)+128=117,5325$

$C r(2,2)=(0,5 \times 25)-(0,42 \times 100)-(0,0813 \times 25)+128=161,13$

$\operatorname{Cr}(2,3)=(0,5 \times 25)-(0,42 \times 100)-(0,0813 \times 25)+128=138,4675$

$C r(3,1)=(0,5 \times 25)-(0,42 \times 100)-(0,0813 \times 25)+128=117,5325$

$C r(3,2)=(0,5 \times 25)-(0,42 \times 100)-(0,0813 \times 25)+128=136,13$

$C r(3,3)=(0,5 \times 25)-(0,42 \times 100)-(0,0813 \times 25)+128=121,9025$

Kemudian hasil dari konversi warna RGB ke YCbCr diperlihatkan pada Gambar 5.

\section{$Y$}

\begin{tabular}{|c|c|c|}
\hline 69.0 & 97.1 & 77.8 \\
25 & 5 & 5 \\
\hline 14.6 & 103. & 35.3 \\
75 & 55 & 25 \\
\hline 89.6 & 88.6 & 33.5 \\
75 & & 5 \\
\hline
\end{tabular}

\section{$\mathrm{Cb}$}

\begin{tabular}{|c|c|c|}
\hline 103. & 115. & 140. \\
1525 & 5 & 5 \\
\hline 119. & 69.5 & 136. \\
7175 & 65 & 2825 \\
\hline 119. & 78 & 165, \\
7175 & & 5 \\
\hline
\end{tabular}

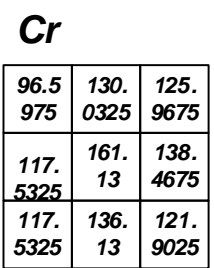

Gambar 6. Hasil Konversi RGB Ke YCbCr

Proses berikutnya adalah pengambilan nilaikuning (Y), yang selanjutnyadimasukanpada filter Gabor. Filter Gabor merupakan proses yang mempertajam tepi-tepi objek, yang bertujuan untuk menandai daerah pembuluh darah retina. Persamaan fungsi gabor diperlihatkan pada Persamaan 2[17].

$G(x, y, f, \theta)=\exp \left[-\frac{1}{2}\left\{\frac{x_{\theta n}^{2}}{\alpha_{x}^{2}}+\frac{y_{\theta n}^{2}}{\alpha_{y}^{2}}\right\}\right] \cos (2 \pi f x)$

Dimana :

Sari AyuWulandari: Perbandingan Tingkat Pengenalan Citra ... $\left[\begin{array}{l}\mathrm{x} ? \mathrm{n} \\ \mathrm{y} ? \mathrm{n}\end{array}\right]=\left[\begin{array}{cc}\sin ? \mathrm{n} & \cos ? \mathrm{n} \\ -\cos ? \mathrm{n} & \sin ? \mathrm{n}\end{array}\right]$

Pada persamaan 2, $\sigma_{\mathrm{x}}$ dan $\sigma_{\mathrm{y}}$ adalah standard deviasi Gaussian Envelope sepanjang $\mathrm{x}$ dan y, sedangkan $\mathrm{f}$ adalah pusat frekuensi gelombang sinusoidal bidang, dan $\theta_{\mathrm{n}}$ merupakan orientasi sudut. Rotasi bidang $\mathrm{x}-\mathrm{y}$ oleh sudut $\theta_{\mathrm{n}}$ akan menghasilkan filter Gabor pada orientasi $\theta_{n}$. Sudut $\theta_{n}$ didefinisikan sebagai pada persamaan 3[17].

$$
\text { ? } \mathrm{n}=\left[\frac{\pi}{p}(n-1)\right]
$$

Pada persamaan 3 nilai $\mathrm{n}=1,2,3 \ldots \mathrm{p}$, dimana $\mathrm{p}$ menunjukkan jumlah orientasi. Hasil dari citra gabor kemudian diambil nilai cirinya.

\section{Vektor Ciri}

Vektor ciri merupakan kumpulan ciri dari nilai komponen warna kuning (Y) pada citra GLCM (Gray Level Coocurrent Matriks). Ciri yang diambil dari GLCM adalah ciri mean, variance, skewness dan entropy dari setiap citra.

1. Mean $(\mu)$ : merupakan rerata dari seluruh matriks segi empat dari GLCM [18].

$\mu=I \times H^{T}$

$I=$ matriks intensitas dari $0-255$

H=Frekuensi kemuculam Angka I

Variance $(\sigma 2)$ : merupakan perhitungan variasi local dari GLCM.

$\sigma 2=(I-\mu)^{2} \times H^{T}$

2. Skewness $(\alpha 3)$ : merupakan perhitungan probabilitas bersama dari pasangan pixel dalam GLCM [18].

$\alpha 3=\frac{(I-\mu)^{3} \times H^{T}}{\left(\sigma 2^{1,5}\right)}$

3. Entropy $(E)$ : merupakan perhitungan distribusi elemen dari GLCM dengan diagonalnya [18].

$E=-H \times \log _{2}\left(H \times 2,22 \times 10^{-16}\right)^{T}$

Dari ke-4 elemen GLCM tersebut, kemudian terbentuklah 4 ciri dari masing-masing citra retinopathy. Berikutnya, vektor ciri akan dimasukan pada bagian ekstraksi ciri.

\section{Ekstraksi Ciri}

Ekstraksi ciri dilakukan dengan menggunakan metode Principle Component Analysis (PCA). Metode ini mempunyai tingkat akurasi yang tinggi. Algoritma metode PCA adalah sebagai berikut [19]:

1. Melakukan perhitungan nilai rerata dari setiap kolom ciri.

2. Membuat matriks baru yang dinamakan matriks reduksi, yaitu nilai matriks dikurangkan dengan rerata ciri tiap kolom.

3. Mencari nilai varian dan kovarian dari matriks reduksi, sehingga dihasilkan matriks baru yang berukuran $4 \times 4$ (matriks simetris dengan ukuran yang sesuai dengan jumlah ciri).

p-ISSN:1693 - 2951; e-ISSN: 2503-2372 
4. Matriks simetri tersebut kemudian dicari nilai eigen value dan eigen vector-nya.

5. Nilai eigen vector diurutkan berdasarkan urutan eigen value tertinggi ke yang terendah.

6. Matriks eigen value yang sudah urut, kemudian dikalikan dengan matriax awal yang sudah ditranspose.

7. Hasil dari perkalian tersebut adalah matriks 4 kolom, dimana 4 kolom tersebut diberi nama PC (Principle Component) PC1, PC2, PC3 dan PC4.

Pada penelitian ini, akan dicari, pasangan PC yang mempunyai nilai akurasi tertinggi.

\section{E. Pengelompokan}

Data vektor ciri akan di kelompokan menjadi 2 kelompok, yaitu kelompok diabet dan kelompok non-diabet, dengan menggunakan metode SVM (Support Vector Machines).

SVM merupakan salah satu metode pengelompokan yang mampu memilah data menjadi 2 kelompok. SVM memisahkan kelompok dengan mencari garis hyperplane (batas kelompok) terbaik. Dalam penelitian ini, garis batas yang dipilih adalah linear, karena garis linear sederhana dalam proses komputasi. Rumus umum dari SVM linear diperlihatkan pada persamaan 8 [20].

$$
f(x)=w^{T} x+b
$$

Dimana $f(x)=-1$ untuk kelompok A dan $f(x)=+1$ untuk kelompok B, sesuai dengan support vektor yang diperlihatkan pada Gambar 7. Margin antara 2 kelompok dihitung dengan mencari jarak dari kedua kelompok. Kecepatan dan akurasi dari pengenalan, dipengaruhi oleh jumlah support vector yang dilibatkan. Hal ini diperlihatkan pada persamaan 9 dan 10[20].

$$
\begin{aligned}
& \left(w x_{1}+b=+1\right)-\left(w x_{2}+b=-1\right) \\
& w\left(x_{1}-x_{2}\right)=2
\end{aligned}
$$

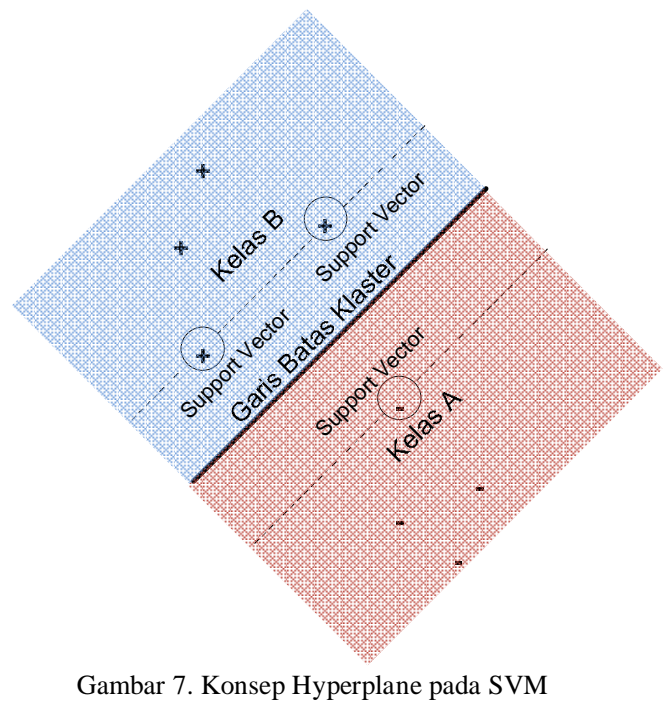

\section{F. Pengujian}

Pengujian dilakukan dengan menggunakan confusion matriks, yaitu metode yang menggunakan tabel untuk menganalisis, seberapa baik, sebuah pengenal pola mampu mengenali kelompok-kelompok berbeda, diperlihatkan pada Tabel 1.

TABEL I

\begin{tabular}{lcc}
\multicolumn{4}{c}{ CONFuSION MATIX } \\
\cline { 2 - 3 } & \multicolumn{2}{c}{ Hasil Deteksi } \\
\hline & Retinopathy $\begin{array}{c}\text { Non- } \\
\text { Retinopathy }\end{array}$ \\
\hline $\begin{array}{l}\text { Retinopathy } \\
\text { Dimana, } \mathrm{TP}=\text { True Positive, } \mathrm{TN}=\text { True Negative, } \mathrm{FP}=\text { F } \\
\text { positive, FN }=\text { False Negative }\end{array}$
\end{tabular}

Dari Tabel 1, digunakan untuk mencari akurasi, sesuai dengan persamaan 11. Nilai akurasi sendiri merupakan nilai prosentase jumlah total prediksi dari citra diabet [21].

$$
\text { Akurasi }=\frac{T P}{T P+F P}
$$

\section{HASIL DAN PEMBAHASAN}

\section{A. Pre-Processing}

Pada tahap pre-processing dilakukan proses citra awal, yaitu mulai dari citra asli (RGB), yang diubah ke ranah YCbCr, lalu diambil kanal Y, kemudian dilakukan operasi gabor dengan sudut $\Theta 30^{\circ}, 120^{\circ}$ dan $150^{\circ}$. Hasil dari operasi gabor merupakan gabungan dari ke-3 sudut $\Theta$, Gambar 8 .

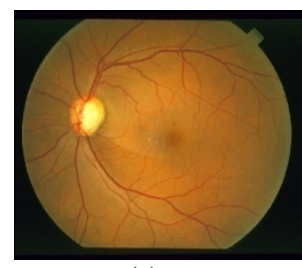

(a)

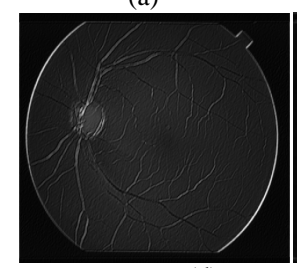

(d)

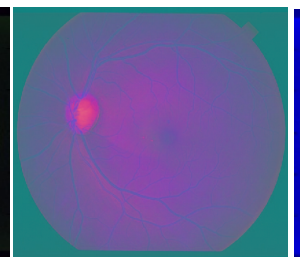

(b)

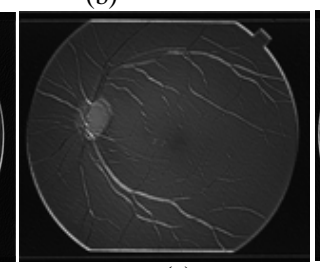

(e)

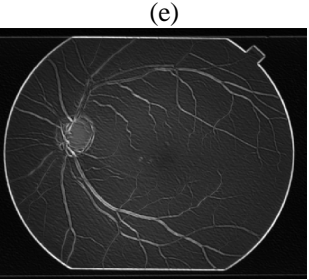

(g)

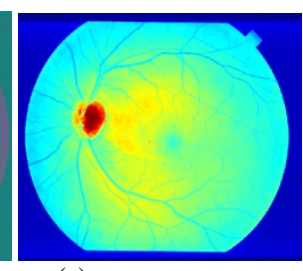

(c)

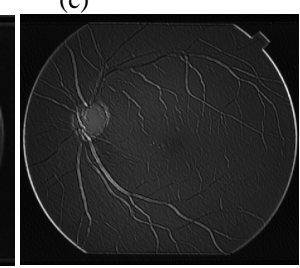

(f)
Gambar 8. (a) Citra Asli, (b)Citra YCbCr, (c) Citra Y, (d) Gabor 30 $0^{\circ}$, (e) Gabor $120^{\circ}$ dan (f) Gabor $150^{\circ}$, (g) Gabor Gabungan

\section{B. Vektor Ciri}

Nilai dari vektor ciri ditunjukan pada Tabel 2.Dari Tabel 2, dapat dilihat bahwa nilai entropi mempunyai kisaran angka ratusan, mean mempunyai kisaran angka puluhan dan skewness pada kisaran satuan. Perbedaan antara diabet dan non diabet terletak pada perbedaan nilai varian. Pada citra diabet, nilai varian pada kisaran satuan sedangkan pada citra non-diabet, nilai varian pada kisaran puluhan. 
TABEL 2

VEKTOR CIRI

\begin{tabular}{cccccccc}
\hline \multicolumn{7}{c}{ Non-Diabet } & \multicolumn{5}{c}{ Diabet } \\
\hline $\boldsymbol{\mu}$ & $\boldsymbol{\sigma 2}$ & $\boldsymbol{\alpha 3}$ & $\mathbf{E}$ & $\boldsymbol{\mu}$ & $\boldsymbol{\sigma 2}$ & $\boldsymbol{\alpha 3}$ & $\mathbf{E}$ \\
\hline 39 & 6 & 3 & 653 & 6 & 39 & 3 & 526 \\
49 & 6 & 2 & 734 & 6 & 45 & 2 & 648 \\
40 & 6 & 3 & 543 & 6 & 34 & 3 & 614 \\
43 & 6 & 2 & 690 & 6 & 36 & 3 & 625 \\
39 & 6 & 3 & 553 & 6 & 36 & 3 & 606 \\
48 & 6 & 2 & 953 & 5 & 34 & 4 & 581 \\
36 & 6 & 3 & 632 & 6 & 36 & 3 & 463 \\
35 & 6 & 3 & 628 & 5 & 35 & 4 & 526 \\
29 & 5 & 4 & 441 & 5 & 34 & 4 & 583 \\
39 & 6 & 3 & 560 & 5 & 35 & 4 & 562 \\
33 & 6 & 3 & 547 & 6 & 53 & 2 & 645 \\
39 & 6 & 2 & 688 & 6 & 47 & 2 & 663 \\
26 & 5 & 4 & 428 & 6 & 37 & 4 & 510 \\
33 & 5 & 4 & 521 & 6 & 36 & 2 & 564 \\
32 & 5 & 4 & 535 & 6 & 36 & 3 & 594 \\
35 & 6 & 3 & 591 & 6 & 46 & 2 & 815 \\
41 & 6 & 2 & 732 & 5 & 32 & 4 & 538 \\
41 & 6 & 3 & 700 & 5 & 33 & 4 & 586 \\
35 & 6 & 3 & 477 & 5 & 33 & 4 & 484 \\
37 & 6 & 4 & 620 & 5 & 32 & 4 & 576 \\
36 & 6 & 3 & 416 & 6 & 38 & 3 & 631 \\
37 & 6 & 2 & 593 & 6 & 38 & 3 & 657 \\
34 & 6 & 3 & 579 & 5 & 32 & 4 & 530 \\
38 & 5 & 4 & 462 & 5 & 32 & 4 & 578 \\
45 & 6 & 3 & 584 & 6 & 37 & 3 & 477 \\
47 & 6 & 2 & 634 & 6 & 28 & 4 & 391 \\
39 & 6 & 3 & 577 & 6 & 38 & 3 & 615 \\
40 & 6 & 3 & 506 & 6 & 33 & 4 & 446 \\
34 & 6 & 3 & 548 & 6 & 38 & 3 & 541 \\
36 & 6 & 3 & 457 & 5 & 31 & 4 & 516 \\
\hline & & & & & & &
\end{tabular}

\section{Ekstraksi Ciri}

Proses ekstraksi ciri merupakan proses pengambilan ciri yang paling menonjol, dan dapat digunakan sebagai pembeda utama dalam pengenalan pola. Dari 4 ciri yang diusulkan,

TABEL 3

\begin{tabular}{cccccccc}
\multicolumn{7}{c}{ HASIL PCA } \\
\hline PC1 & PC2 & PC3 & PC4 & PC1 & PC2 & PC3 & PC4 \\
\hline 1.7 & 0.1 & 0.2 & -0.1 & -1.2 & 0.7 & -0.8 & 0.0 \\
2.8 & 1.1 & 0.0 & 0.2 & -0.7 & 2.1 & -0.5 & 0.1 \\
1.5 & -0.5 & -0.8 & 0.0 & -0.7 & 1.2 & -0.2 & -0.2 \\
2.3 & 0.7 & -0.1 & 0.0 & -1.0 & 1.0 & 0.2 & -0.1 \\
1.3 & -0.7 & -0.4 & 0.0 & -0.8 & 1.2 & -0.3 & -0.2 \\
3.5 & 2.5 & 1.6 & 0.0 & -1.6 & 0.0 & 0.8 & 0.0 \\
1.3 & -0.4 & 0.5 & -0.1 & -1.4 & 0.1 & -1.1 & 0.0 \\
1.1 & -0.6 & 0.7 & -0.1 & -1.6 & -0.1 & 0.1 & 0.0 \\
-0.4 & -2.4 & 0.4 & 0.0 & -1.5 & 0.1 & 0.7 & 0.0 \\
1.2 & -0.7 & -0.2 & 0.1 & -1.4 & 0.3 & 0.2 & 0.0 \\
1.0 & -0.6 & -0.4 & -0.2 & -0.9 & 2.4 & -0.7 & 0.4 \\
2.0 & 0.6 & 0.1 & -0.1 & -0.6 & 2.4 & -0.6 & 0.1 \\
-0.5 & -2.4 & 0.2 & -0.1 & -1.8 & -0.1 & 0.0 & 0.2 \\
0.1 & -1.9 & 0.8 & 0.1 & -0.7 & 1.2 & -1.0 & -0.2 \\
0.2 & -1.6 & 0.7 & 0.0 & -1.1 & 0.8 & 0.0 & -0.1 \\
1.1 & -0.6 & 0.2 & -0.1 & 0.0 & 3.3 & 0.5 & 0.0 \\
2.3 & 0.8 & 0.4 & -0.1 & -1.8 & -0.5 & 0.7 & 0.0 \\
2.0 & 0.5 & 0.4 & 0.0 & -1.6 & -0.1 & 1.0 & 0.0 \\
1.1 & -0.8 & -1.3 & -0.2 & -1.6 & -0.2 & -0.4 & -0.1 \\
1.1 & -0.7 & 0.7 & 0.1 & -1.5 & 0.0 & 0.7 & -0.1 \\
0.5 & -1.8 & -1.0 & 0.1 & -1.0 & 1.2 & 0.2 & 0.0 \\
1.6 & 0.0 & -0.6 & -0.2 & -1.0 & 1.2 & 0.5 & 0.0 \\
0.9 & -0.8 & 0.3 & -0.1 & -1.6 & -0.3 & 0.3 & -0.1 \\
0.4 & -2.0 & -0.1 & 0.2 & -1.7 & -0.2 & 1.0 & 0.0 \\
1.7 & -0.5 & -0.3 & 0.3 & -1.6 & -0.1 & -0.7 & 0.1 \\
2.3 & 0.2 & -0.4 & 0.2 & -2.2 & -1.7 & -0.2 & 0.0 \\
1.4 & -0.4 & -0.3 & 0.0 & -1.2 & 0.8 & 0.4 & 0.1 \\
1.0 & -1.3 & -0.3 & 0.2 & -2.0 & -0.9 & -0.2 & 0.1 \\
0.9 & -0.9 & 0.0 & -0.1 & -1.0 & 1.0 & -1.0 & -0.1 \\
1.0 & -1.1 & -1.3 & -0.1 & -1.8 & -0.6 & 0.5 & 0.0 \\
\hline & & & & & & &
\end{tabular}

Sari AyuWulandari: Perbandingan Tingkat Pengenalan Citra ...
Tabel 2, akan diekstrak menjadi 2 ciri dengan menggunakan metode PCA. Table 3 merupakan hasil dari ekstraksi ciri PCA.

Tabel 3 memperlihatkan hasil ekstraksi ciri PCA. Hasil PCA kemudian diamati nilai akurasi, berdasarkan 6 pasangan PC, yaitu PC1 dan PC2, PC1 dan PC3, PC1 dan PC4, PC2 dan PC3, PC2 dan PC4 serta PC3 dan PC4.

\section{Pengelompokan}

Sistem pengelompokan, dilakukan untuk memisahkan antara kelompok citra diabet dan kelompok citra non-diabet, dengan menggunakan metode SVM. Gambar 9 akan memperlihatkan hasil pengelompokan SVM.

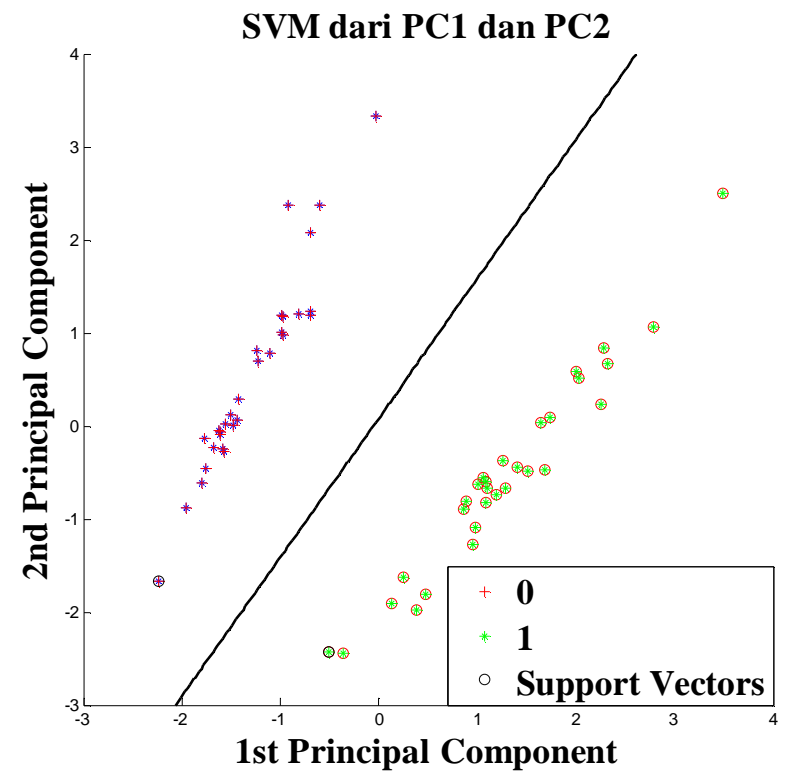

(a)

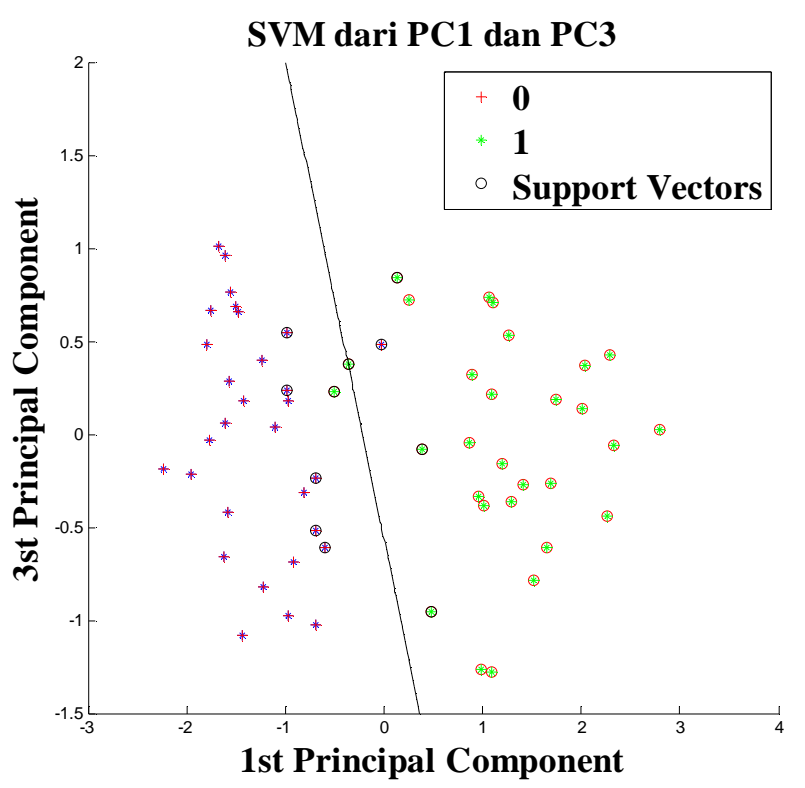

(b) 


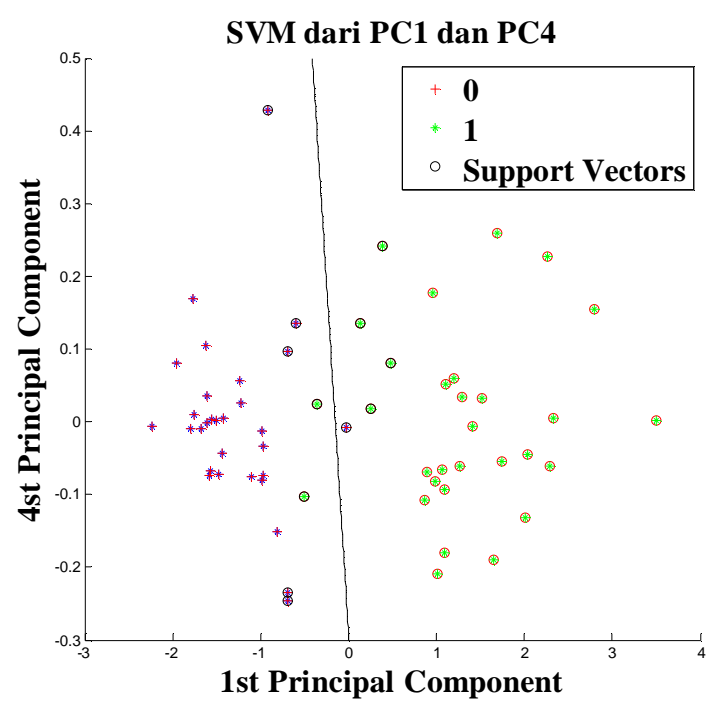

(c)

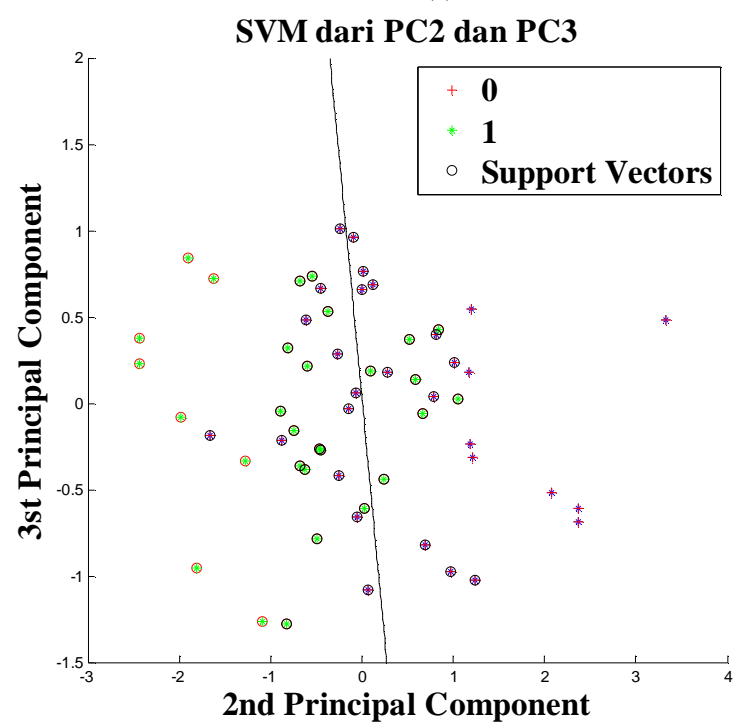

(d)

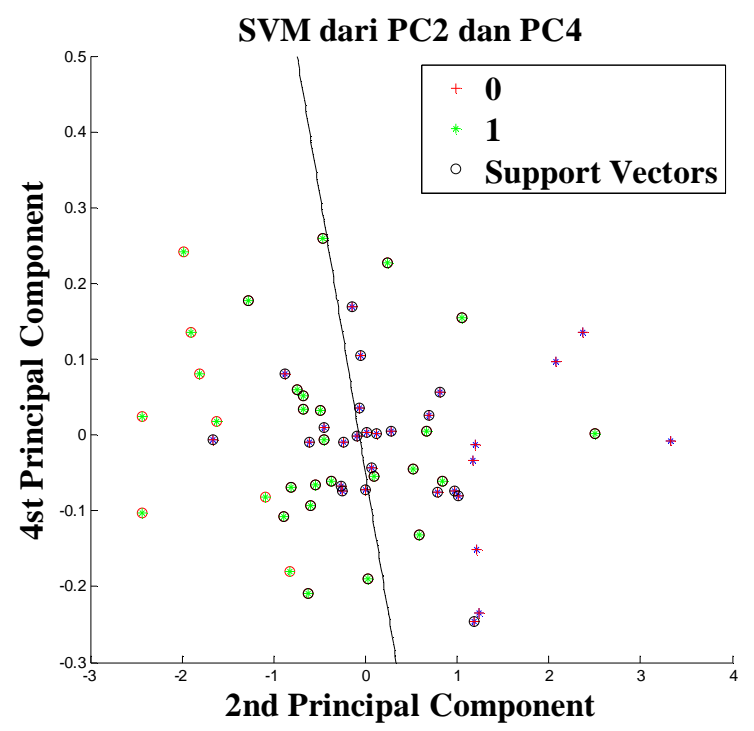

(e)

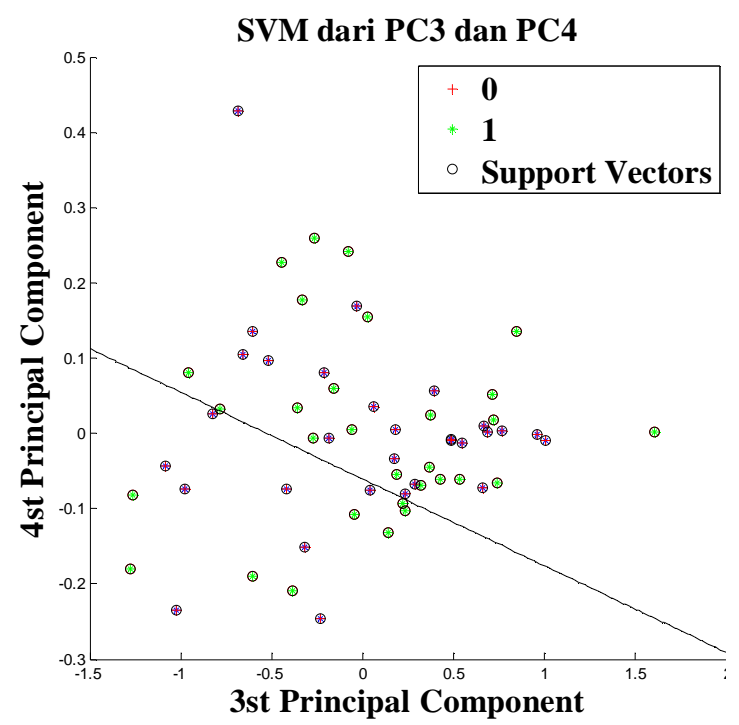

(f)

Gambar 9. (a) PC1 \& PC2, (b) PC1 \& PC3, (c) PC1 \& PC4, (d) PC2 \& PC3, (e) PC2 \& PC3, (f) PC3 \& PC4.

Hasil dari plot grafik scatter dari keseluruhan pasangan PC yang diperlihatkan pada Gambar 9(a) menunjukan bahwa scatter mempunyai sebaran yang menyatu antar kelompok, sehingga lebih terlihat pemisahan pola-nya. Perhitungan persamaan garis batas diperlihatkan pada Tabel 4 .

TABEL 4

HASIL PENGELOMPOKAN

\begin{tabular}{|c|c|c|}
\hline & $\Sigma$ Support Vektor & Persamaan Garis \\
\hline PC1 \& PC2 & 2 & $y=x-0.0425$ \\
\hline PC1 \& PC3 & 11 & $y=x-0.3227$ \\
\hline PC1 \& PC4 & 12 & $y=x-0.2257$ \\
\hline PC2 \& PC3 & 44 & $y=x-0.0054$ \\
\hline PC2 \& PC4 & 44 & $y=x+0.0701$ \\
\hline PC3 \& PC4 & 60 & $y=x-0.2071$ \\
\hline
\end{tabular}

Dari Tabel 4 dapat dilihat bahwa, pasangan PC1 dan PC2 mempunyai support vektor paling sedikit dari pasangan $\mathrm{PC}$ yang lain. Artinya pasangan PC1 dan PC2 membutuhkan waktu proses yang relatif lebih pendek dibandingkan dengan pasangan PC yang lain.

\section{E. Pengujian}

Pengujian dilakukan dengan menggunakan Tabel 1 dan persamaan 7. Hasil persamaan 7 diperlihatkan pada Tabel 5.

TABEL 5

\begin{tabular}{llllll} 
& \multicolumn{6}{l}{ HASIL TINGKAT AKURASI $(\%)$} \\
\hline Pasangan & TP & TN & FP & FN & Akurasi \\
\hline PC1 \& PC2 & 30 & 0 & 0 & 30 & 100 \\
PC1 \& PC3 & 29 & 1 & 1 & 29 & 97 \\
PC1 \& PC4 & 29 & 1 & 2 & 28 & 94 \\
PC2 \& PC3 & 23 & 7 & 11 & 19 & 68 \\
PC2 \& PC4 & 22 & 8 & 10 & 20 & 69 \\
PC3 \& PC4 & 8 & 22 & 8 & 22 & 50 \\
\hline
\end{tabular}

Model yang disimpan adalah model persamaan akhir dari PCA, yaitu matriks eigen vektor diperlihatkan pada Tabel 6 . 
TABEL 6

EIGEN VEKTOR

\begin{tabular}{cccc}
\hline \multicolumn{4}{c}{ EIGEN VEKTOR } \\
\hline 1 & $1.9 \times 10^{-16}$ & 0 & $2.2 \times 10^{-16}$ \\
\hline $1.9 \times 10^{-16}$ & 1 & $5.5 \times 10^{17}$ & $-1.1 \times 10^{-16}$ \\
\hline 0 & $5.5 \times 10^{-17}$ & 1 & $2.8 \times 10^{-17}$ \\
\hline $2.2 \times 10^{-16}$ & $-1 \times 10^{-16}$ & $2.8 \times 10^{-17}$ & 0.9 \\
\hline
\end{tabular}

Persamaan batas diperlihatkan pada Persamaan 12 - 14 . $\mathrm{y}=\mathrm{x}-0.0425$

dengan :

Non-Diabet jika $\mathrm{y}<\mathrm{x}-0.0425$

Diabet jika $y>x-0.0425$

Hasil dari pengujian, 30 citra diabet dan 30 citra non diabet, dimana citra yang digunakan adalah citra diluar citra belajar, diperlihatkan pada Gambar 10.

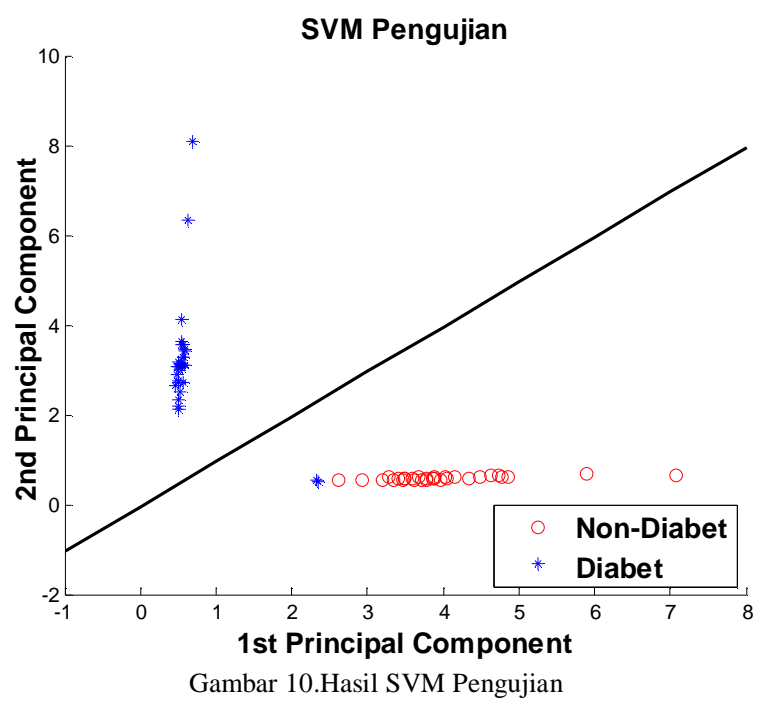

Dari hasil prosentase akurasi data pengujian diperlihatkan pada Tabel 7.

TABEL7

HASIL AKURASI PENGUJIAN

\begin{tabular}{llllll}
\multicolumn{7}{c}{ HASIL } & AKURASI PENGUJIAN \\
\hline Pasangan & TP & TN & FP & FN & Akurasi \\
\hline Pengujian & 30 & 0 & 2 & 28 & 93,75 \\
\hline
\end{tabular}

Hasil akurasi dari citra pengujian adalah 93,75\%, hal ini masih belum optimal. Hal ini kemungkinan disebabkan oleh melebarnya daerah cakupan, dari batas -1 sampai 4 untuk pembelajaran, dan -10 sampai 80 untuk citra pengujian.

\section{KESIMPULAN}

Pada penelitian perbandingan tingkat pengenalan citra diabetic retinopathy pada kombinasi Principle Component dari 4 ciri berbasis metode SVM (Support Vector Machine) ini, dapat ditarik kesimpulan bahwa Model dengan akurasi tertinggi dan tercepat adalah model pasangan PC1 dan PC2, yang mempunyai akurasi citra pembelajaran tertinggi yaitu Sari AyuWulandari: Perbandingan Tingkat Pengenalan Citra ...
$100 \%$ dan waktu tercepat, yang secara eksplisit diperlihatkan pada jumlah support vektor terkecil, yaitu 2. Pasangan yang mempunyai tingkat akurasi terburuk adalah PC3 dan PC4. Pengenalan turun pada citra pengujian, yaitu hanya $50 \%$, hal ini disebabkan oleh pelebaran daerah cakupan. Pelebaran daerah cakupan kemungkinan disebabkan oleh pemilihan nilai rerata pada PCA, sebelum matriks reduksi. Pada penelitian berikutnya, bisa dilakukan dengan menggunakan pencarian nilai standart deviasi atau varians, dengan begitu, akan diketahui matriks reduksi yang mewakili sebaran angka pada matriks.

\section{UCAPAN TERIMAKASIH}

Terima kasih disampaikan kepada Diknas Jawa Tengah, yang telah menyumbangkan dana penelitian, dalam program Hibah Fasilitasi Jawa Tengah Tahun Anggaran 2015.

\section{REFERENSI}

[1] American, 2010. "Evidence-Based Practice Guideline, Care of the Patient with Diabetes Mellitus,".

[2] Haniza Yazid; Hamzah Arof; Hazlita Mohd.Isa."Automated Identification of Exudates and Optic Disc Based on Inverse Surface Thresholding”, Journal Medicine System, LLC 2011 .

[3] Ulinuha M;Purnama I; Hariadi M. 2010."Segmentasi Optic Disk Pada Penderita Diabetic Retinopathy Menggunakan GVF Snake".

[4] Ahmed Wasif Reza; C.Eswaran, Subhas Hati. "Automatic Tracing of Optic Disc and Exudates From Color Fundus Image Using Fixed and Variable Thresholds", Journal Medicine System, Springer Science, LLC 2008.

[5] Wei Bu; Xiangqian Wu; Xiang Chen; Baisheng Dai; Yalin Zheng. "Hierarchical Detection of Hard Exudates in Color Retinal Images", Journal of Software, Vol.8, No.11, November 2013, pp. 2723 - 2732.

[6] Flavio Araujo; Rodrigo Veras; Andre Macedo; Fatima Medeiros."Automatic Detection of Exudate in Retinal Images Using Neural Network" 2011.

[7] Brigitta Nagy; Balazs Harangi; Balint Antal; Andras Hajdu."Ensemblebased Exudate Detection in Color Fundus Image", 7th International Symposium on Image and Signal Processing and Analysis (ISPA), Dubrovnik, Croatia, September 2011.

[8] S.Fowjiya. Dr.M.karnan. Mr.R.Sivakumar.2013.An Automatic Detection and Assessment of Diabetic Macular Edema Along With Fovea Detection from Color Retinal Images. International Journal of Computer Trends and Technology (IJCTT) - volume4Issue4 -April 2013

[9] M. Usman Akram, Shehzad Khalid, Anam Tariq, M. Younas Javed, 2013. "Detection of Neovascularization in Retinal Images using Multivariate m-Mediods based Classifier", Elsevier Journal of Computerized Medical Imaging and Graphics

[10] Siva Sundhara Raja, S.Vasuki, Rajesh Kumar.2014. Performance Analysis Of Retinal Image Blood Vessel Segmentation. Advanced Computing: An International Journal (ACIJ), Vol.5, No.2/3

[11] A. S. Jadhav dan Pushpa B. Patil. 2015. Classification Of Diabetes Retina Images Using Blood Vessel Area. International Journal on Cybernetics \& Informatics (IJCI) Vol. 4, No. 2

[12] A.Osareh Dan B. Shadgar. 2009. Automatic Blood Vessel Segmentation In Color Images Of Retina. Iranian Journal of Science \& Technology, Transaction B, Engineering, Vol. 33, No. B2, pp 191-206

[13] Nilanjan Dey, Anamitra Bardhan Roy, Moumita Pal,Achintya Das. 2012. FCMBased Blood Vessel Based Blood Vessel Based Blood Vessel

[14] Segmentation Method for Retinal Images. International Journal of Computer Science and Network (IJCSN). Volume 1, Issue 3

p-ISSN:1693 - 2951; e-ISSN: 2503-2372 
[15] Adithya Kusuma Whardana dan Nanik Suciati. 2014. A Simple Method for Optic Disk Segmentation.from Retinal Fundus Image. I.J. Image, Graphics and Signal Processing, 2014, 11, 36-42

[16] Sulaiman Santoso dan Erico Darmawan. 2015. Kombinasi Penggunaan Model Warna dalam Pendeteksian Letak Bibir pada Gambar Digital Berwarna. Jurnal Teknik Informatika dan Sistem Informasi. Vol 1. No 2.

[17] Amin Padmo dan Murinto. 2016. Segmentasi Citra Batik Berdasarkan Fitur Tekstur Menggunakan Metode Filter Gabor dan K-Means Clustering. Jurnal Informatika Vol 10. No 1. 